\title{
Technology Roadmap of IGCC Industry in China
}

\author{
Yun Guo ${ }^{1,2 *}$, Zhiqiang Huang ${ }^{3}$, Zhiguan Zhou1 \\ ${ }^{1}$ College of Mechanical Engineering, Shanghai University of Engineering Science, Shanghai, China \\ ${ }^{2}$ Department of Mechanical and Aerospace Engineering, Rutgers, The State University of New Jersey, \\ New Brunswick, NJ, USA \\ ${ }^{3}$ College of Engineering Science and Technology, University of Shanghai for Science and Technology, Shanghai, \\ China \\ Email: "graceguo1977@126.com
}

Received 25 July 2015; accepted 26 October 2015; published 29 October 2015

Copyright (C) 2015 by authors and Scientific Research Publishing Inc.

This work is licensed under the Creative Commons Attribution International License (CC BY). http://creativecommons.org/licenses/by/4.0/

(c) (i) Open Access

\section{Abstract}

With the increasing energy demand and environmental pressures caused by consumption of fossil fuels, the world casts their eyes on new energy, hoping to transform the existing energy structure through technological innovation to new energy field, to promote the optimization and upgrading of the world's energy structure. The new energy in key areas of Chinese high-tech industries includes mainly nuclear power, wind power, solar power, IGCC (Integrated Gasification Combined Cycle), new energy vehicles and smart grids. The present paper will carry on an in-depth study on IGCC industry technology roadmap in China. Technology roadmap is a kind of technology management tool, expressing the structure and time dimension of technical elements' evolution with icons. It spans a wide range of applications from a single company to industry, and national and international coalition, from detailed product technology to component technology, as well as the integration of several relevant industry technologies. The roadmap is a kind of multi-layered time-dependent icon. IGCC industry has excellent environmental characteristics and benefits, which are in accordance with the principle of coordinated development between energy and environment. Based on the analysis of current situation, market demand, industry objectives and technical barriers of IGCC technology, we highlight IGCC industrial development model with Chinese characteristics, and concisely propose the major research needs and technology projects of key technology areas in IGCC industry. We highlight IGCC industrial development model with Chinese characteristics, and concisely propose the major research needs and technology projects of key technology areas in IGCC industry. Furthermore, some relevant suggestions on IGCC technology management and industry development are put forward to promote the remarkable progress in the development of IGCC industry in China and build an efficient, economical and clean sustainable energy supply system in line with the requirements of low-carbon economy.

\footnotetext{
${ }^{*}$ Corresponding author.
} 


\section{Keywords}

\section{Technology Roadmap, IGCC Power Plant, Coal Gasification Technology, Technology Innovation}

\section{Introduction}

With the signing of the Kyoto Protocol (1997) and with the implementation of initiatives passed at global climate summit held in Copenhagen (2009), and the Bali follow-up roadmap (2007), the era of low-carbon economy, has arrived. Developing efficient and clean energy vigorously has become a new trend in energy sector around the world including China.

New energy is a strategic industry, against which we can measure the level of development of high-tech of a country or a region. It is also the strategic high ground for a new round of international competition. China is breaking a new path in energy sector by means of highly independent innovation and accelerating the development pace of new energy high-tech industry so as to give impetus to the new energy industry which is designed to become the driving-engine for a new round of economic development in China. Currently, the development of Chinese new high-tech energy industries is mainly focused on nuclear energy, wind power, IGCC, solar and smart grid industry. The present paper's main concern involves in the IGCC industry and it is hoped that our research can shed some light on the development path of Chinese IGCC industry as well as its future direction.

\subsection{Background}

Coal has always been the main source of energy in China. Even by twenty-first century, China's coal proportion in primary energy consumption is still above 50\%. In the near future, the coal used to generate electricity is expected to account for more than $80 \%$. In China, direct combustion of coal has always been the main source of serious environmental pollution, and more than $70 \%$ of pollutants in the air such as $\mathrm{SO}_{2}, \mathrm{NO}_{\mathrm{x}}$, mercury, particulate matter and $\mathrm{CO}_{2}$ come from direct combustion of coal.

Therefore, how to develop low-carbon industry in a coal-dominant country and how to efficiently and reasonably make use of coal, which accounts for $60 \%$ of China's total energy consumption, is of paramount realistic importance.

Development and use of Clean Coal Technology (CCT) is the only way out [1]. Clean coal technology refers to the technology used to reduce pollution and improve production efficiency in the process of development and utilization of coal, which is designed to maximize the use of coal and to limit the release of pollutants to its lowest level. Integrated gasification combined cycle (IGCC) power generation technology is one of the most promising clean coal technology.

The basic technological process of IGCC technology is shown in Figure 1. Coal or other carbon-containing

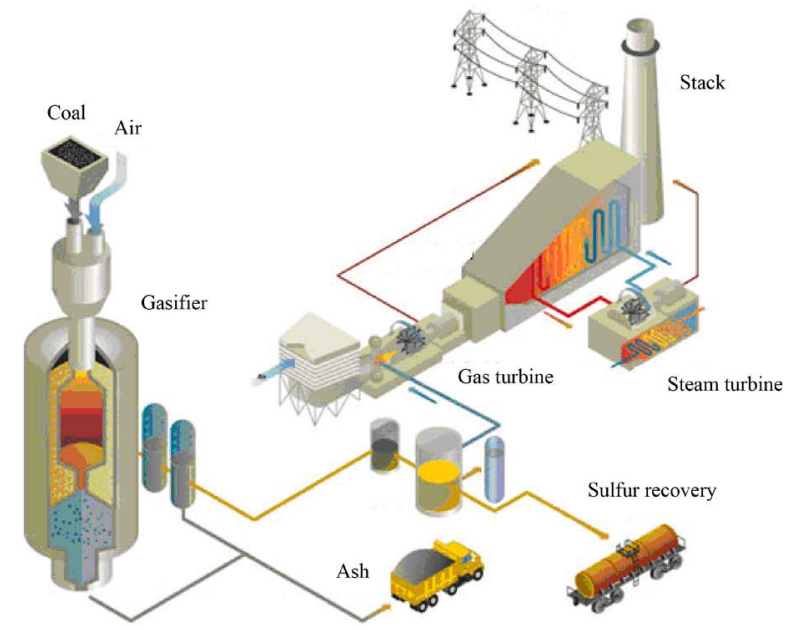

Figure 1. IGCC system diagram. 
fuels, such as petroleum coke, biomass and other low calorific value synthetic gas generated by the gasification, after dust removal, desulfurization and other purification, form clean synthesis gas, which is supplied to drive gas-burning turbines. The exhaust heat from gas turbine and recovery heat from gasification island pass through the waste heat boiler and produce superheated steam, which drive steam turbine for power generation, thus achieving the gasification gas-steam combined cycle power generation [2].

As an advanced clean coal power generation technology, IGCC enjoys unique advantages in the quasi-zero $\mathrm{CO}_{2}$ emissions [3]. Therefore, it becomes the focus of new energy development of the high-tech industrialization in China. Strategically speaking, IGCC will undoubtedly play an important role in safeguarding Chinese energy safety, combating oil shortages and improving environmental quality.

\subsection{Mission and Vision}

Technology roadmap is a comprehensive conclusion reached through accommodating various views of interested stakeholders, in line with the expected target. Its longitudinal direction is a combination of goals, tasks and resources, and its lateral direction is the union of past, present and future. Therefore, it both describes the present and predicts the future. Based on the actual requirements of the national energy strategy and energy industries, the main tasks of technology roadmap for the development of Chinese IGCC include the followings: understanding the status of industrial development, characteristics and trends in the world; analysis of China IGCC development situation; determining the future IGCC development goals through analyses of market demands elements, technical barriers, and research and development needs; drawing IGCC industry technology roadmap (2010-2030) based on industrial objectives, development needs, technical route and other factors; and finally, making recommendations on technology management and industrial development of IGCC.

\section{Status of IGCC Industry}

In recent years, a considerable amount of manpower, material and financial resources has been invested in high-tech research for new energy, and quite a number of research results have been obtained. A lot of research papers related to new energy technologies have been published, as shown in Figure 2.

The number of research papers on IGCC is obviously fewer than that of papers on other fields, which indicates that IGCC technology is a relatively latecomer compared with others new energy forms. Figure 3 shows the distribution of IGCC world patented technology. In recent decades, continued research and development of IGCC technology has entered into a new rapid development stage; in particular major breakthroughs have been achieved in theoretical studies.

Several IGCC demonstration projects have been brought forward internationally [4] [5]. The "FutureGen" plan has been put forward in the United States. In this plan, America will build many IGCC demonstration projects, which set carbon dioxide capture and storage, power generation, hydrogen production into one and with

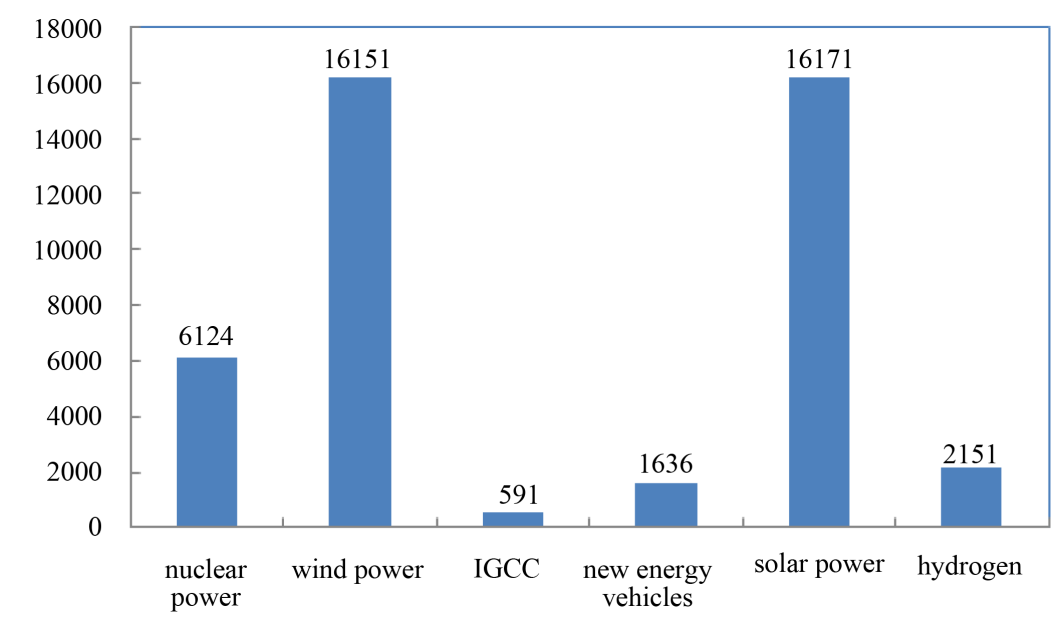

Figure 2. The statistics of new energy-related research papers in the period of 1991-2010 (Web of Science). 


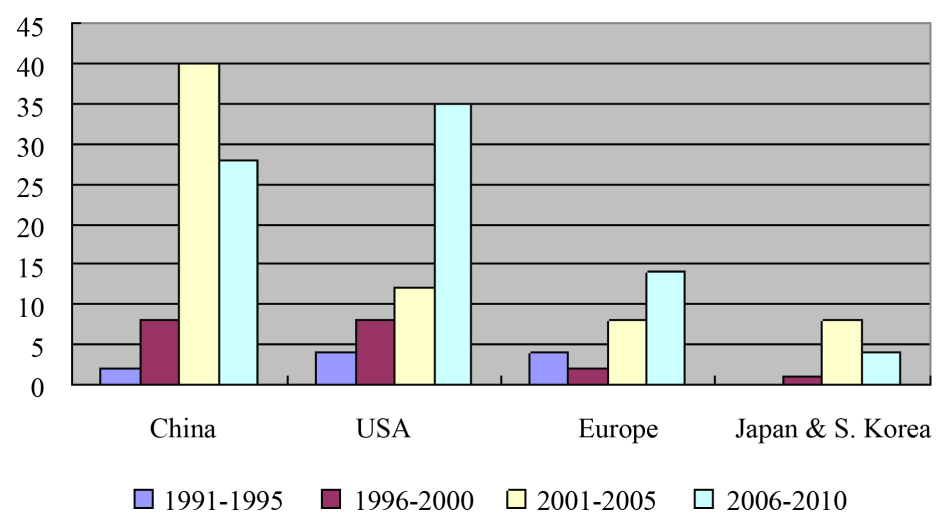

Figure 3. IGCC patent technology world source distribution (Derwent World Patents Index).

more than 300 MW capacity [6]. The plan has ever been suspended due to some financial constraint. Japan brought forth building Integrated Gasification Fuel cell Combined Cycle (IGFC) demonstration projects to improve energy efficiency and $\mathrm{CO}_{2}$ capture and storage. Europe also planned to construct five IGCC demonstration power projects, in which developing new mode $\mathrm{CO}_{2}$ zero emission, coal-based power generation technology [7] is considered. Australia ZeroGen demonstration project was aimed at building the world's first commercial scales coal-fired power plant of low emission power generation by combining gasification with CCS technology in 2017 [8].

Most of these IGCC projects have included or considered issues of carbon dioxide capture and disposal. China should learn a great deal from the trends and characteristics shown in these projects in terms of determining the development direction of Chinese IGCC demonstration power plants [9] [10].

The five top power generation groups in China have also planned to raise their IGCC power generation. At present, there are nine IGCC projects under building or planning and five in feasibility study status. Among them, China Huaneng Group (CHNG) "GreenGen" Project (as shown in Figure 4) is aimed at developing and demonstrating the integrated coal gasification, hydrogen production, hydrogen power generation and $\mathrm{CO}_{2}$ sequestration system, and achieving high coal-based generation efficiency and zero emission of all pollutant and $\mathrm{CO}_{2}[11]$.

In conclusion, feasibility studies and preparatory construction work have paved the way for IGCC technology engineering. But the matter of the fact is that there is also a lack of a more daring engineering practice in China. The government energy agency should accelerate the approval of the qualified representative IGCC projects, and promote the construction of demonstration projects of different technical directions.

\section{IGCC Technology Roadmap Research Methods and Processes}

The designing and compilation of this roadmap is done on the basis of the principles of industry technology roadmap [12], using effective methods of organization and following scientific workflows. By following the path of "status analysis-market demand analysis-technical barriers-R\&D needs analysis-road map designing" it tries to define IGCC industry technology roadmap development process in China, as is shown in Figure 5.

In the process of research and preparation of IGCC technology industry roadmap, by using documents such as data mining and analysis of strategic intelligence tools to improve efficiency and enhance the systematic study, the research team has visited relevant departments and industry associations so as to understand the government polices and plans; and through discussion with research institutes, the team tried to understand the technical edge and research enterprise's information. The research team also listened to businesses' ideas before a comprehensive view is reached. The plan takes into consideration of the interests of various stakeholders, and is in sync with the projected target and is the scientific basis for government decisions.

\subsection{Market Demand Factor Analysis}

IGCC technology represents the trend of multi-generation coal power generation and utilization technology development, and it is also an effective way to get rid of the dependence on oil, and plays an important role in the 


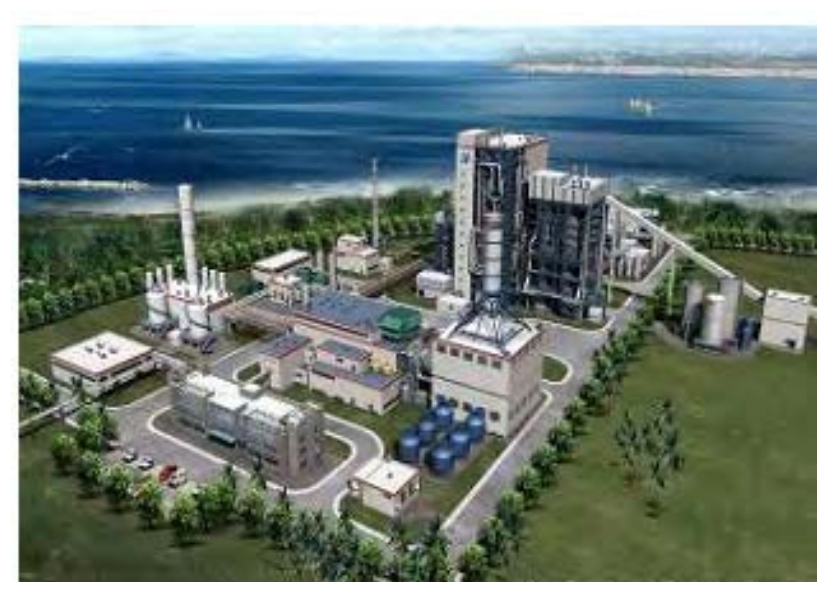

Figure 4. Tianjing IGCC power plant.

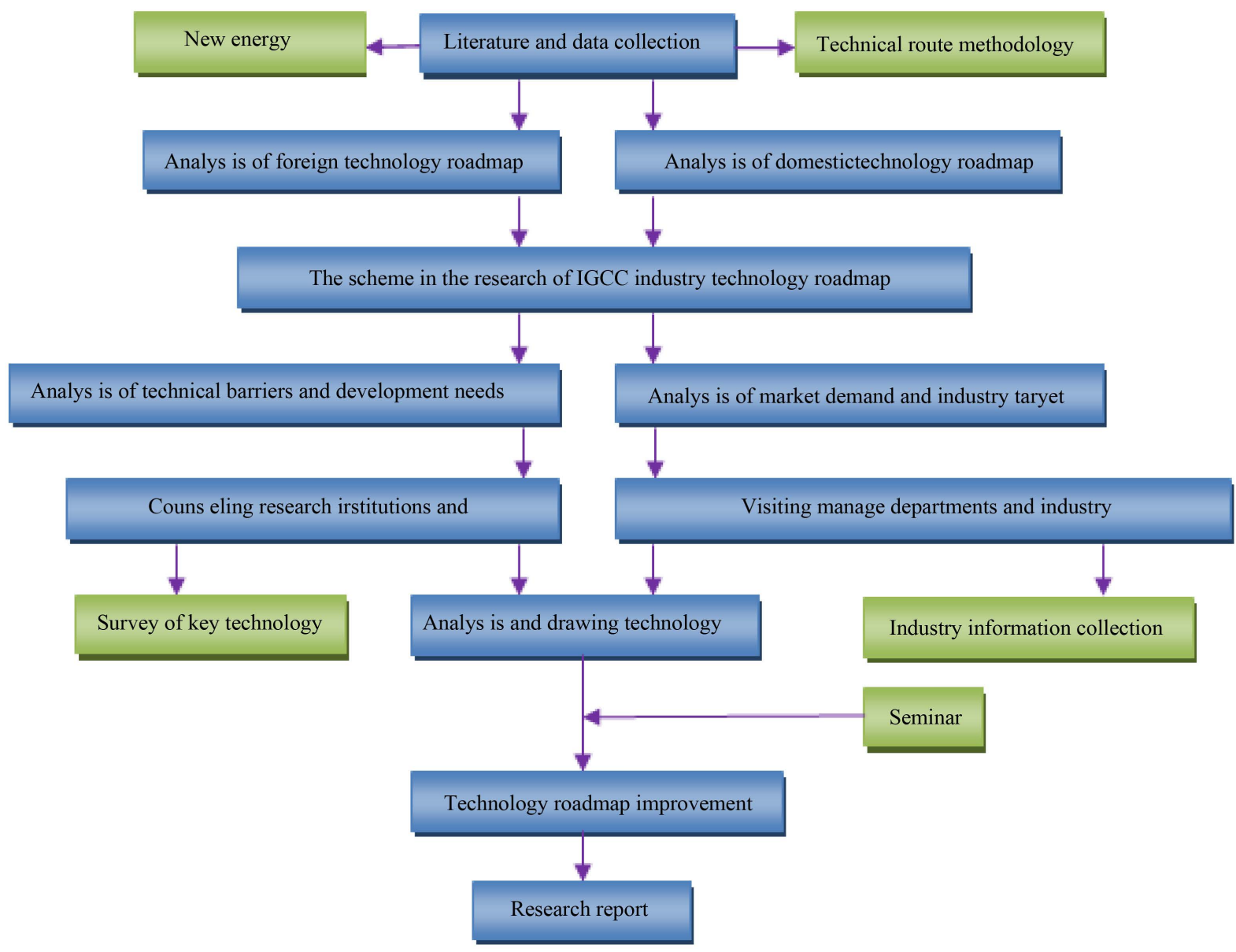

Figure 5. IGCC industry road mapping workflow.

development of new energy. Although the reliability of IGCC power plant in the early stage is indeed lower than traditional power plants, but as the technology matures, this problem will be solved. Scientists have made a lot of efforts in this regard. Through technical innovation, the cost of power plant operations will be lowered gradually and its market share in the low-carbon economy will be growing in the future.

Through comprehensive analysis of the energy market research, and ranking of elements of energy demand, the market demand factors for the development of IGCC industry in China are ultimately identified in the fol- 
lows (Table 1).

\subsection{Industry Target Analysis}

The IGCC industry target elements are finalized after seminars and extensive information research through various channels. The IGCC industry target elements are arranged in the order of importance with value of importance descending from the bottom to the top (see Table 2).

\subsection{Industrial Linkage Analysis}

IGCC industry is a new direction in the development of the energy industry, which is inseparable from the development of IGCC technology research and support other related industries. Associated industries and the correlation factor of those industries with the IGCC industry sector is shown in Figure 6.

As can be seen from the industry association radar chart, the industry that has the highest correlation with the IGCC industry is heavy machinery manufacturing industry. IGCC key devices cannot be obtained without the support of major equipment manufacturing industry, so it is necessary to make full use of the manufacturing advantages in major equipment manufacturing industry to achieve breakthroughs in equipment manufacturing. In the order of importance, other associated industries related to IGCC are as follows: industrial raw materials, followed by coal industry, environmental industry, chemical industry, transportation, education, finance, construction, warehousing, services and communication industry.

\subsection{Technical Barriers}

Detailed analysis has been made about the impact of industrial technical barriers, the evolving processes of various technologies and the features and situation of key technology application based on IGCC industry market demands. The path to further improving the performance of the system is to enhance the efficiency of its technical components and sub-systems and lower manufacturing costs. The key technology areas are summarized as follows.

1) Large-capacity, high-performance gasifier

The pressurized coal gasifier suitable for power generation must continue to improve its performance and

Table 1. The market demand factors for IGCC development.

\begin{tabular}{ccc}
\hline Priorities & Demand factors \\
\hline 1 & Improve the efficiency of IGCC power generation net (currently only about $42 \%)$ \\
2 & Lower initial investment costs \\
4 & Enhanced controllability of the system \\
5 & IGCC economic aid industry \\
\hline
\end{tabular}

Table 2. The target elements for the development of IGCC industry in China.

$\begin{array}{cc}\text { Priorities } & \text { Goal factors } \\ 1 & \text { Improve IGCC overall efficiency (about 58\%) } \\ 3 & \text { Improve the design and manufacturing capabilities and level } \\ 4 & \text { Strengthening the capacity of complete sets of equipment } \\ 5 & \text { Enhance system operation stability and controllability adjustment } \\ 6 & \text { Improve the overall quality of industry management } \\ 7 & \text { To further reduce carbon emissions } \\ 8 & \text { Technology to improve the social service system }\end{array}$




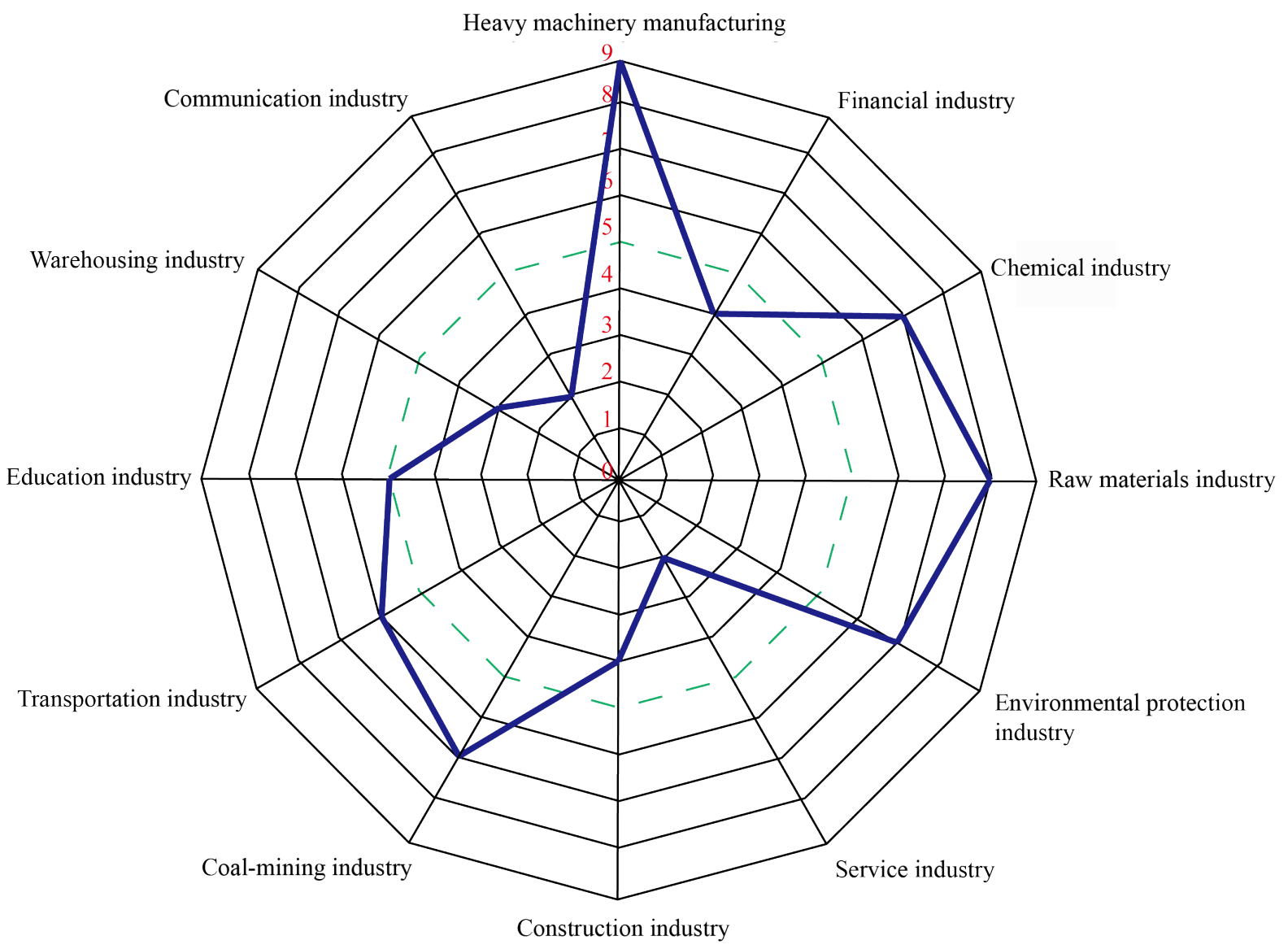

Figure 6. IGCC related industries associated radar.

operating availability and reliability. The availability of IGCC power plants currently in operation depends largely on the availability of the gasifier. The gasifier (3000 t/d or above) is indispensable for large-economicscale IGCC project. Although a jet bed has an advantage in this regard, its potential to further improve the thermal performance is limited. Integration of different technologies and interpenetration is expected to make a big breakthrough in gasification technologies, such as fluidized bed combustion and gasification technology convergence technology, the furnace and the furnace outer gas desulfurization solid complementary purification technologies. The technology can effectively remove most of the sulfur in the coal gasification process, thus simplifying or eliminating the gas purification equipment that is otherwise needed.

In terms of performance improvement of the gasifier, particular emphasis should be put on the need to improve the carbon conversion and gas-cooling efficiency. In terms of improving the operational availability, special attention should be paid to improving high-temperature furnace lining (brick) and the nozzle life, and to optimizing the design of gasifier slag systems. Besides, the adaptability of coal gasifier should be further improved, with a view to exploring the design of different kinds of coal gasifier for different types of coal.

2) The new air separation equipment

Cryogenic legal oxygen equipment is currently used in IGCC power plants. The disadvantage of cryogenic air separation is its huge energy consumption (about $10 \%-15 \%$ of total plant electricity). Besides, the equipment is very expensive. The interval between the time to start and the time to stop is several hours; therefore it is not conducive to peaking-adjusting. In order to improve the efficiency of IGCC power, it is necessary to develop new equipment with membrane technology or pressure swing adsorption (PSA) oxygen way, whose power consumption is only one-third of that of the deep cold technology. The interval between start and stop is only seconds, and it is easy to achieve large-scale target, which is conducive to improving the IGCC peaking power plant efficiency and performance. The international community is developing advanced membrane separation technology with a view to effectively mass-producing oxygen at low cost. 


\section{3) High-temperature gas turbine performance}

The development of a stand-alone gas turbine with greater power, higher initial gas temperature, and lower heat consumption rate is important and should be used as the core part around which to optimize the allocation of other parts of IGCC. Continuously raising initial gas temperature by use of improved high-temperature materials and cooling technology is still the main trend in the development of gas turbines. The G gas turbine units, which are being commercialized, have reached the limits of initial temperature of the traditional air-cooled technology and materials. The $\mathrm{H}$ technology, currently being developed, characterized by the use of more efficient steam cooling technology, super alloys and advanced thermal barrier coating technology (directionally solidified and single crystal blades), as well as advanced aerodynamic design thermodynamic methods (such as controlled expansion pressure principle) and low $\mathrm{NO}_{\mathrm{X}}$ burners, etc., is expected to raise the initial gas temperature to $1400^{\circ} \mathrm{C}-1600^{\circ} \mathrm{C}$.

With the upgrade of temperature resistant materials, the efficiency of the gas turbine is expected to be further improved.

\section{4) High-temperature gas purification equipment}

The study of ash-removing and desulfurization method under high temperature conditions is an important direction in the simplification of the future IGCC system and the lowering of cost of proportion investment, that is, the process of removing ashes and getting rid of sulfur under the high temperature of $500^{\circ} \mathrm{C}-600^{\circ} \mathrm{C}$ thus improving the system thermal efficiency, and simplifying the system and reducing the proportion investment cost.

\subsection{Research and Development Needs Analysis}

Priority order of key technical difficulties, time nodes and development modes have been identified after fully considering the analyses put forwarded in three stages, that is, IGCC market demand analysis, industry analysis, and objective analysis of the problem of technical barriers. See Table 3.

\section{Table 3. IGCC development needs analysis.}

\begin{tabular}{|c|c|c|c|}
\hline Key technology & Priorities & $\begin{array}{l}\text { Time node } \\
\text { (years) }\end{array}$ & Development model \\
\hline $\begin{array}{l}\text { Large variety of raw materials } \\
\text { gasification process research }\end{array}$ & High & $0-8$ & Research \\
\hline Large-scale gasification equipment and technology & Top & $0-5$ & $\begin{array}{l}\text { Combined with the introduction of } \\
\text { digestion and research }\end{array}$ \\
\hline $\begin{array}{l}\text { Gasification system control } \\
\text { and regulation systems technology }\end{array}$ & Middle & $0-8$ & Production and research \\
\hline Oxygen, air separation equipment manufacturing & High & $0-8$ & Independent \\
\hline Oxygen technology and theory & Middle & $0-5$ & Research \\
\hline $\begin{array}{l}\text { Oxygen combustion technology } \\
\text { and related theories }\end{array}$ & Middle & $0-5$ & Research \\
\hline $\begin{array}{l}\text { Chemical looping combustion } \\
\text { theory and technology }\end{array}$ & Middle & $0-5$ & Research \\
\hline $\begin{array}{l}\text { Development of high-performance } \\
\text { gas turbine equipment }\end{array}$ & Top & $0-10$ & $\begin{array}{l}\text { Combined with the introduction } \\
\text { of digestion and research }\end{array}$ \\
\hline Crude gas purification technology & High & $0-5$ & Research \\
\hline $\begin{array}{l}\text { Synthesis gas purification } \\
\text { system control and regulation }\end{array}$ & Middle & $0-8$ & Production and research \\
\hline HRSG design and manufacturing technology & High & $0-5$ & Independent \\
\hline Waste heat recovery system control and regulation & Middle & $0-8$ & Production and research \\
\hline CCS technology in-depth study & High & $0-15$ & Research \\
\hline Complete system integration technology equipment & High & $0-10$ & Research \\
\hline System control and regulation technology & High & $0-10$ & Research \\
\hline
\end{tabular}




\subsection{Drawing Technology Roadmap of IGCC Industry in China}

Judging from IGCC development in various countries, the construction of pilot power plants is the first step in the development of IGCC. Based on the needs of our national economy and energy development, the demonstration project should be aimed at the development and research of IGCC core technology. In terms of the characteristics and development direction, the government will actively support the development of IGCC industry efforts and vigorously build industrial bases for IGCC technology research, development, production and operation. After a full range, multi-level analysis, we have basically mastered the domestic mid-term and long term IGCC industry R\&D tasks, technical barrier breakthroughs, the industrial goal to be achieved, the market demands to be met. Now a final conclusion is presented in the form of technology roadmaps as shown in Figure 7.

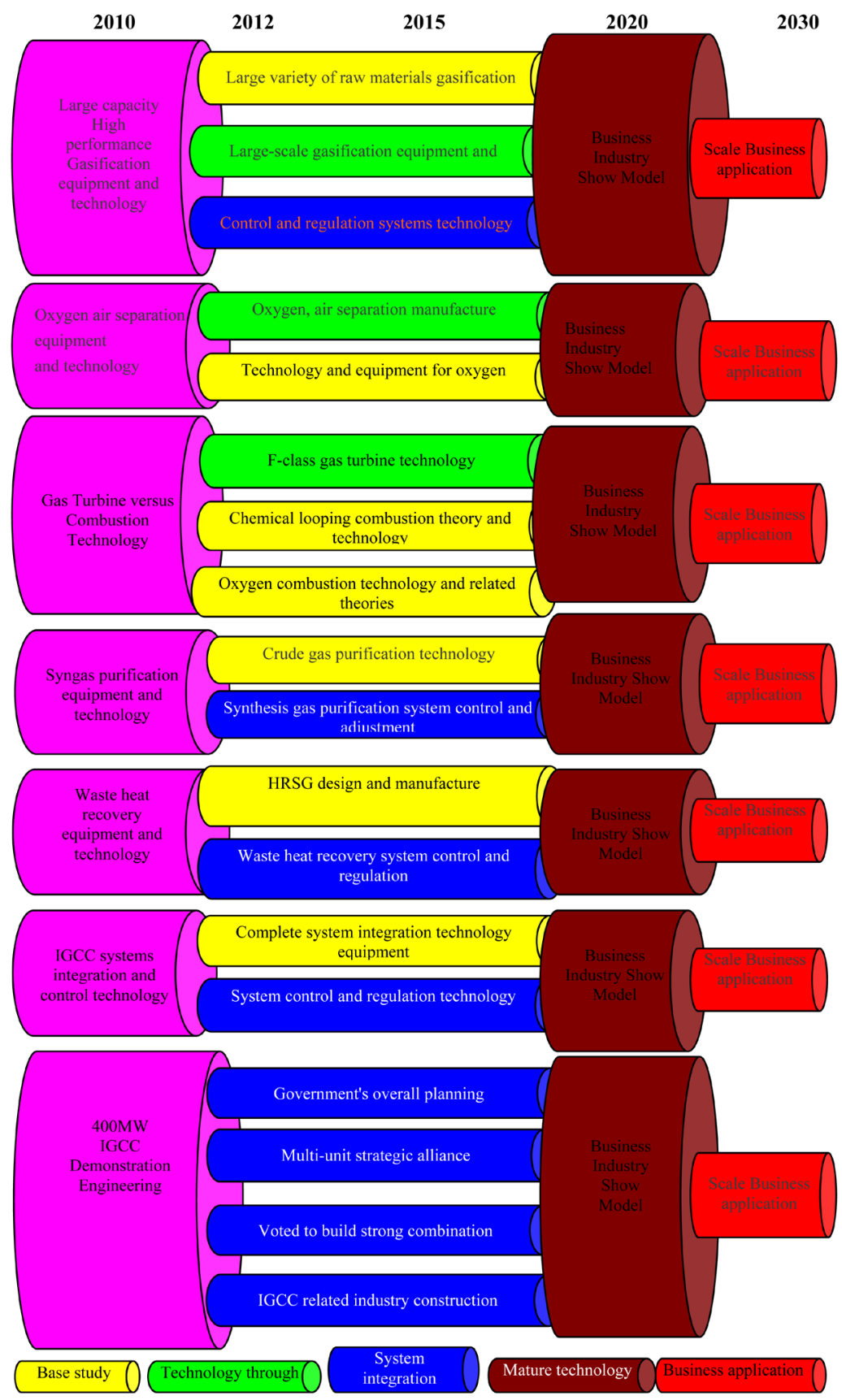

Figure 7. China IGCC industry technology roadmap. 


\section{Suggestions on China's Development of IGCC Industry}

IGCC technology will be an important basic industry in the development of the new energy economy in the future. China's IGCC industry development must be combined with China's national conditions, and it must be carried out by means of sound and scientific decision-making, planning and coordinated arrangement [13]. Based on these principles, we put forward the following recommendations:

1) Firstly, we need to view it from the angle of the long-term national energy planning and strategy, and actively seek state support, and try to get it included in the list of IGCC technology and education projects in the hope of getting long-term funding from the state. Having these favorable conditions, an integrated research and industrial base for IGCC technology research, development, production and operation can be constructed.

2) China's IGCC development should be implemented by enhancing independent innovation capability, owning intellectual property, mastering the ability to manufacture core equipment, mastering the core technology of high-end industry and improving the core competitiveness of the industry in these aspects. By mustering strength in scientific research, a joint research team should be set up which should be composed power-generating groups, power-generating equipment manufacturing research groups, chemical companies, research institutes. The objective of the joint team is to solve difficult problems in IGCC technology and elevates our competitiveness in the international energy industry.

3) Promoting the construction of the demonstration bases. Special attention should be paid to the development of IGCC gas turbines, gasification, power plant systems integration, speedy construction of key IGCC demonstration projects. By using demonstration project as carrier, research should focus on breakthroughs in key equipment manufacturing, speedy development of low calorific value gas turbine combustor, large-scale power plant systems integration and other technology. Other priorities include: promoting the construction of public service platforms such as gas turbine engineering technology centers; enhancing capabilities in common technology research and development and service; and maintaining the status of international leadership in key equipment IGCC design and manufacturing and system integration capabilities. Efforts should also be made to promote the cooperation and co-production between demonstration projects and their neighbouring chemical companies so as to raise the utilization efficiency of IGCC.

4) Promoting and keeping track of upstream and downstream key projects of the IGCC industry chain; strengthening the butting and matching of associated industrial projects and IGCC so as to achieve exemplar and demonstration effect. Organizers of industrial bases and main projects need to make concrete action plan to speed up industrial applications and large-scale production as soon as possible.

5) Further enhancing the relationship between the cost and the performance of the gasification and IGCC technology in the commercial range. Not only should we improve China's industrial gasification applications, we should also promote the deployment of commercial scale IGCC plant by using carbon capture technology. We should strive to become the integrated gasification and clean coal technology service provider in the international market by means of technology, operational and professional services concept.

\section{References}

[1] Yan, W.P. (2008) Clean Coal Power Generation Technology. China Electric Power Press, Beijing.

[2] Shi, Q., Wu, X.J. and Xu, X.Y. (2009) IGCC Power Plant with Energy Conservation and Emissions Reduction. Energy Conservation Technology, 27, 18-20.

[3] Harry, J. (2007) IGCC Power, How Far-Off. Gas Turbine World, 37, 15-19.

[4] Dong, S.M., Wang, Z.H. and Liu, B. (2009) Overview of IGCC Power Plant Project in the World. Gas Turbine Technology, 22, 15-19.

[5] Li, X.Y., Sun, Y.B. and Li, H.M. (2009) Brief Description of Current Status of IGCC Projects in Foreign Countries. Electric Power Design, 6, 28-33.

[6] Chris, H. (2008) European Coal Gasification Projects. FutureGen Workshop, Tokyo.

[7] Heleen, D.C., Todd, F. and Paul, C. (2009) The Acceptability of $\mathrm{CO}_{2}$ Capture and Storage (CCS) in Europe: An Assessment of the Key Determining Factors. International Journal of Greenhouse Gas Control, 3, 333-343. http://dx.doi.org/10.1016/j.ijggc.2008.07.009

[8] Martin, O. (2008) ZeroGen-New Generation Coal Technology. 2008 GTC Conference, Washington DC, October, USA.

[9] Guo, Y. (2010) Advances in Integrated Gasification Combined Cycle System with Carbon Capture and Storage Tech- 
nology. International Conference on Advances in Energy Engineering, Beijing, China, June, 363-366.

[10] Guo, Y. (2012) The Prospects and Challenges of Carbon Capture and Storage Technology. Chemical Industry and Engineering Progress, 6, 145-148.

[11] Xu, S.S. and Gao, S.W. (2009) $\mathrm{CO}_{2}$ Capture, Utilization and Storage Technology in Coal-Fired Power Plant. Shanghai Energy Saving, 9, 8-13.

[12] Li, X.H. (2008) The Principles of Industry Technology Roadmap and Development. Science and Technology Press, Guangdong, China.

[13] The Energy Strategy of the Chinese Academy of Sciences Research Group (2009) China’s Energy Technology Development Roadmap Until 2050. Science Press, Beijing. 